\title{
Live Enrollment for Identity Documents in Europe: The Cases of Sweden, Norway, Kosovo, and Estonia
}

\section{Tarmo Kalvet*, Henrik Karlzén**, Amund Hunstad***, Marek Tiits****}

* Institute of Baltic Studies and Tallinn University of Technology, Akadeemia tee 3, Tallinn 12618, Estonia; tarmo.kalvet@taltech.ee;

** Swedish Defence Research Agency, SE-164 90 Stockholm, Sweden; henrik.karlzen@foi.se;

*** Swedish Defence Research Agency, SE-164 90 Stockholm, Sweden; amund. hunstad@foi.se;

**** Institute of Baltic Studies, Lai 30, Tartu 51005, Estonia; marek@ibs.ee.

Abstract: Digital image alterations (morphing) of identity document photos is a major concern, and may potentially allow citizens with malicious intent to enroll for identity document(s) later in order to be used by another individual. Taking the photo in the application office -live enrollment -can address this issue. However, this is a break with tradition and entails a sizeable overhaul in the public sector, which can be reluctant to change and of ten lacks the necessary formal methods that ensure a smooth transition. The objective of this paper is to map the main barriers and drivers related to live enrollment based on theoretical research and interviews conducted with high-ranking officers at passport authorities in Estonia, Kosovo, Norway, and Sweden. These countries have successfully switched to live enrollment. The main motivation for live enrollment has been increased security; for Estonia, user convenience was important and was behind the decision of keeping alternative application processes for the citizens. The absence of legacy systems makes it easier to implement public sector innovations, such as live enrollment. Behind the successful implementation is proper risk management: covering technological, political, and organizational risks. Finally, the research results indicate varying experiences, obstacles, cultural differences, and trade-offs, while emphasizing the need to understand barriers and drivers in a contextualized way.

Keywords: Identity document, live enrollment, social acceptance, public sector innovation, drivers and barriers

Acknowledgement: This work was supported by the European Commission through the project "Fast and trustworthy Identity Delivery and check with ePassports leveraging Traveler privacy" (FIDELITY, grant 284862) funded from FP7 and a grant "Public sector innovation: The case of modern identity management technologies" (PUT773) from Estonian Science Foundation. 


\section{Introduction}

Existing facial recognition algorithms are unable to fully deal with digital image alterations ${ }^{1}$. This means that malicious citizens are able to apply for identity documents that can be used by another individual. When a photo is brought in, the photographer, the applicant, and others involved all must trust that the photo has not been tampered with. In theory, biometric facial recognition algorithms should be able to determine altered photos from genuine ones, but, in practice, the algorithms are not perfect.

While the live enrollment of fingerprints is a common standard for identity documents, such as European passports, this is not the case for passport photos. The non-live photo enrollment procedure is vulnerable to 'morphing attacks' (Ferrara et al., 2014), in which a digitally altered photograph is enrolled in order to allow two or more persons of similar appearance to use the same passport to pass visual checks of their face (both automated and manual) at border crossing points. This would mean that a known criminal could travel with the passport of somebody else. More generally, if one does not make sure that the photo is an authentic representation of the person applying for the passport (and nobody else), the photo will not provide the intended security. For example, someone may be forced to apply for a passport with somebody else's photo, resulting in identity-theft. Meaning, that somebody could travel in the name of the coerced person (on identity theft in Europe, see Kalvet et al., 2018a). This could be useful for a criminal involved in e.g., illegal immigration or human trafficking. The adoption of a common standard for live enrollment of passport photos may eliminate, or at least greatly reduce, these threats.

As of 2016, only some European countries have switched to full live enrollment (Figure 1). Some countries are applying a mixed approach where live enrollment is offered as an option, while most of the European countries are still applying a traditional approach where applicants bring their photos with them. Primarily, Northern and South-Eastern European countries have made live photo enrollment mandatory. Meanwhile, a number of larger member states, such as France, Italy, Spain, and the UK, have not yet launched live enrollment. In some cases, the existence of live enrollment varies at the intra-country level; for instance, it is available only in a third of Swiss cantons and various German municipalities.

The objective of this paper is to explain the main drivers and barriers behind switching to live enrollment. These are vital to understanding the problem at hand, its possible solutions, and to propose policy recommendations to other countries. It is important to note that there might not be one best model suitable for all countries as cultural and economic differences must be considered.

\footnotetext{
${ }^{1}$ Earlier version of the article has been published as Kalvet, T., Karlzén, H., Hunstad, A., Tiits, M. (2018). Live Enrollment for Identity Documents in Europe. In: Parycek, P.; Glassey, O., Janssen, M., Scholl, H.J., Tambouris, E., Kalampokis, E., Virkar, S. (Eds) Electronic Government. 17th IFIP WG 8.5 International Conference, EGOV 2018, Krems, Austria, September 3-5, 2018, Proceedings. Springer: Lecture Notes in Computer Science, pp. 29-39. This extended version is elaborated with further theoretical and, most importantly, with empirical insights.
} 
The research is primarily carried out in four countries-Estonia, Kosovo (Kosovo is recognized as a country by most, but not all, EU member states), Norway, and Sweden-in the issuance of passports. These countries represent a variety of practices. In Kosovo, Norway, and Sweden live enrollment is mandatory. Estonia, on the other hand, represents a country where a mixed approach is in place. These countries represent an economically, socially, and culturally diverse group of countries; therefore, they were selected as case study countries for this research. Furthermore, for several of these countries live enrollment has already existed for quite a few years, which allows for the evaluation of the implementation challenges and long-term effects.

Figure 1: State of the live photo enrollment in the Europe

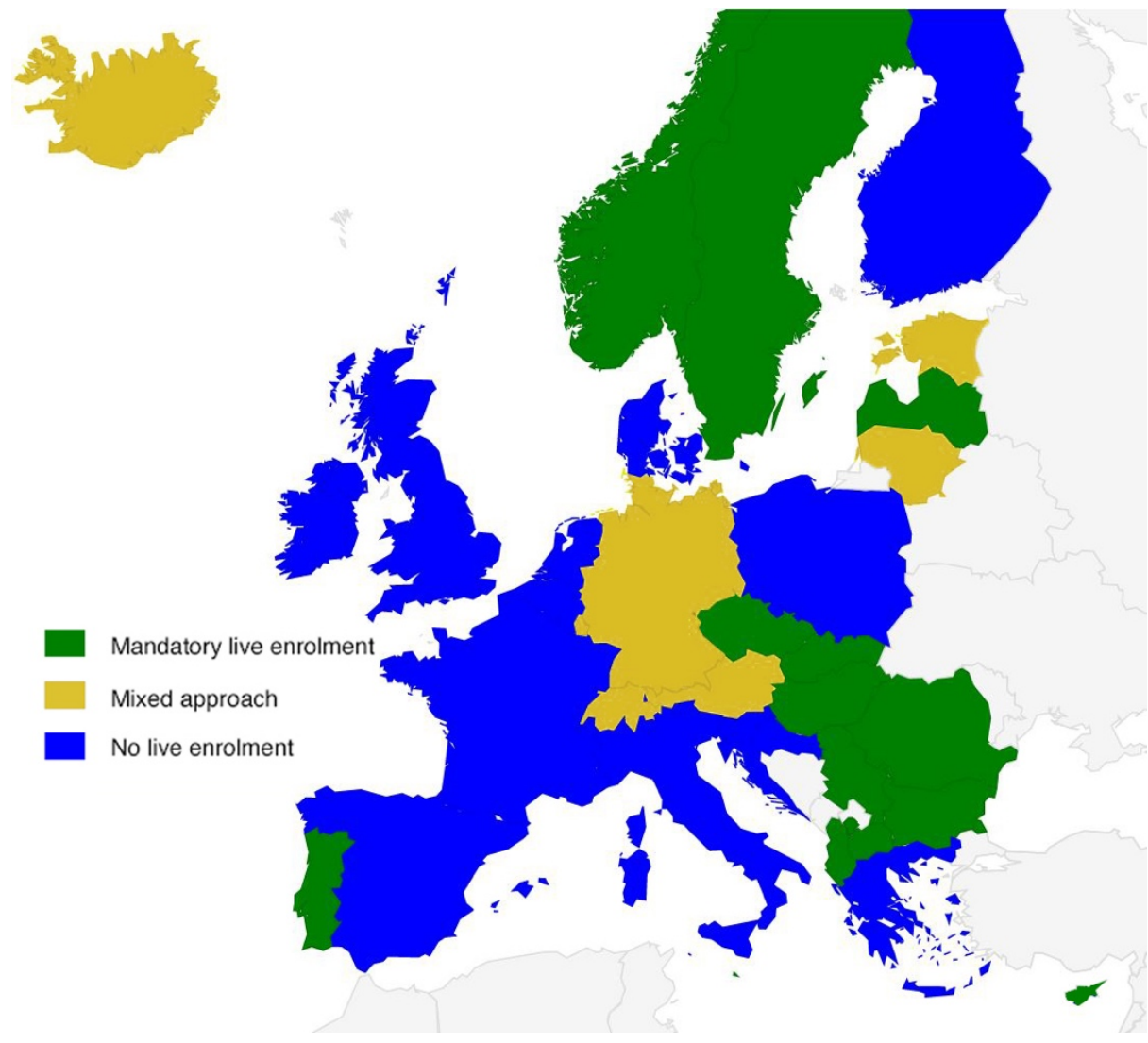

Source: Authors on the basis of national experts participating in the "Sixty-sixth meeting of the Committee on a uniform format for visa" (16 March 2016, Brussels) and on national passport application websites.

As the first step, a review of existing academic and policy literature was conducted to search for influential factors that may affect the implementation of live enrollment. Since the specific topic is scarcely discussed in literature, the literature search was expanded to involve academic papers and policy reports on public sector innovation and technology acceptance. As a result, an inventory of potential barriers and drivers was compiled-covering technological issues, organizational, user aspects, and other relevant factors. 
For the second step, interviews were carried out with high-ranking persons at passport authorities of each of the four countries (for interview guide, see Annex I). The respondents-all government employees with a top-level passport process responsibility (currently or previously)-were selected to be knowledgeable and have good insight into the matter at hand. Care was taken to make clear to the respondents that the aim was not to scrutinize the work of legislature or the passport authority. For privacy reasons, the respondents' names are not given here. Apart from government employees, there were other stakeholders who could have been interviewed. However, passport authorities are the most immediately involved in live enrollment together with applicants, who typically each have limited experience of the process as they typically only apply once every few years. Another possible stakeholder group to interview could have been photographers. However, one reason not to speak to them directly was that those photographers who suffered the most economically due to live enrollment would be less likely to still be in business. Furthermore, it can be a sensitive topic: both for photographers who have suffered, and due to the fact that live enrollment may be spreading. Also, the underlying issue of morphing is a complex security issue, perhaps not easily explained and discussed with other stakeholders, at least without revealing possibly sensitive information.

Interviews were either conducted in person or by phone. Interview responses were documented both on paper and with audio, with the agreement of each respondent. The audio recordings were used in case some of the notes were not sufficiently clear.

The paper is structured as follows: In section two, a general overview of the live enrollment processes in Sweden, Norway, Kosovo, and Estonia is provided. This is followed by a literature review in section three. In section four, the formulation of several hypotheses about challenges and experiences of full live enrollment as based on the theoretical studies and previous empirical work takes place. Section five, discusses the findings, then followed by the conclusions (section six).

\section{Live Enrollment Processes in Sweden, Norway, Kosovo, and Estonia}

In Sweden, there is only one way of applying for a passport, and it is in person at a passport application office where a facial image is taken. This includes taking a digital photo and it is not possible for the applicant to receive a copy of the photo. The system was introduced in 2005. The current process is illustrated by (Figure 2), and is based on the website of the Swedish Police and the interview with their representative.

1) The applicant goes to the passport (police) application office. The entire process is in one spot and in front of the passport officer.

2) The fee is paid and the applicant identifies him/herself with some sort of valid ID.

3) A digital photo is taken. It is not possible for the applicant to receive a copy of the photo. The contract with the company providing the equipment used for taking the photo will expire soon, and there will be a new contract and a new procurement for 2017.

4) A manual comparison is made between the newly captured photo and any previous passport photos stored in the system. In the future, this will be a computer assisted check.

5) The applicant's index fingers are scanned. In case of injuries on the index fingers, another finger will be used. If it is not at all possible to scan any fingers, only a temporary passport 
can be issued. Children below the age of six will not leave fingerprints. Fingerprints, photo, as well as other personal data will be stored on the passport chip. Fingerprints are only stored on the chip. The applicant also provides a signature.

6) The passport rendering is shown to the applicant.

7) The applicant chooses in which application office to pick up the passport when ready.

8) One working week is usually enough to make the passport.

9) The old passport (if still valid) must be temporarily handed in for revocation at the time of the new passport application or pickup. There are, however, exceptions to this.

10) The facial image on the chip is manually compared with the applicant's face when the applicant picks up the passport. The Swedish police want to start checking fingerprints when applicants pick up their passports (in 2017 depending on political will and IT support).

11) The passport is ready and the applicant can begin travelling.

Figure 2: Application for passport and delivery in Sweden

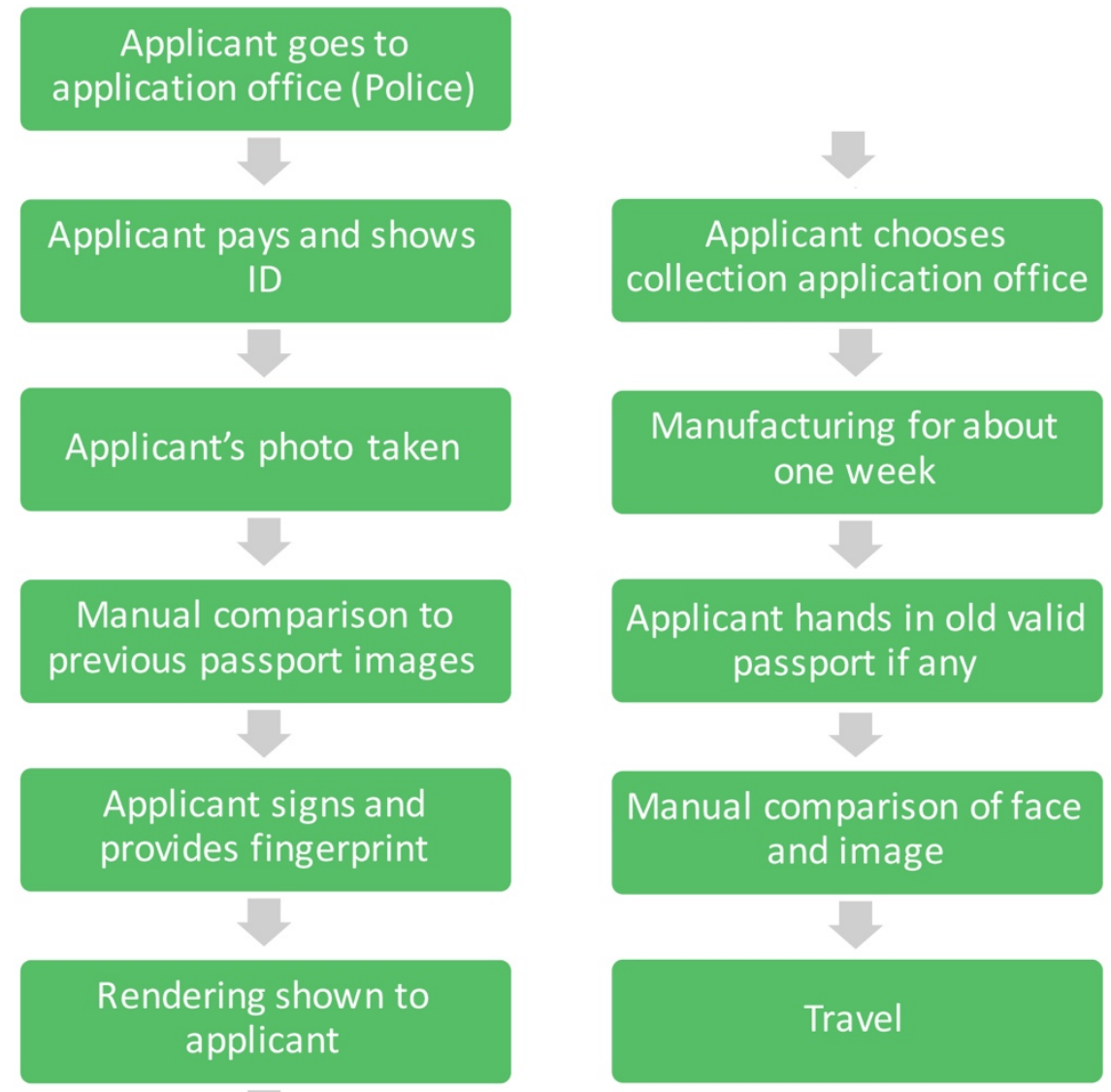

Norway's process is highly similar to the Swedish one, but manufactured passports are sent out by certified mail. It was introduced in 2005.

In Kosovo, also, live enrollment is in place: a digital photo is taken close to the table of the clerk.

Estonia, an example of a typical mixed enrollment process, accepts three different modes of the submission of passport photos, since 2007: 
1) Live enrollment: Passport application with photo is taken in a special photo booth, which links the digital photo with the personal identity code of the person. An important difference to e.g. the Swedish case is that the photo booths are self-service rather than operated by application office staff. The differences may have implications for both quality and security.

2) Traditional application for passport on a paper along with printed photo, submitted in person to Estonian Police and Border Guard Board, or sent in by postal mail.

3) Electronic passport application (filled in PDF form) together with photo in JPG format in the same electronically signed document (BDOC).

Application by post or e-mail is possible only when less than two years have passed from the last collection of fingerprint image, if the applicant is a child under age of 12 years, or one applies ( as an exception) for a passport without fingerprint images that is valid for one year. Otherwise, fingerprints are taken from the applicant together with the passport application and photo in the office of the Estonian Police and Border Guard Board or the foreign representation of the Republic of Estonia.

Documents generally required for applying include:

1) an application form (possible to fill in on a computer screen or to print out and fill in by own hand). An application form shall be filled in when applying by post and by e-mail. Instructions are included for filling in of an application form;

2) an identity document;

3) a color photo by dimensions of $40 \times 50 \mathrm{~mm}$ or minimal measurements of a digital color photo be submitted by e-mail are $600 \times 800$ pixels (the format is JPG);

4) a document certifying the payment of state fee. ${ }^{2}$

${ }^{2}$ For further details, see see https://www.politsei.ee/en/teenused/isikut-toendavad-dokumendid/eestikodaniku-pass/taiskasvanule/index.dot 
Table 1: The general passport background in Sweden, Norway, Kosovo, and Estonia

\begin{tabular}{|c|c|c|c|c|}
\hline & Sweden & Norway & Kosovo & Estonia \\
\hline $\begin{array}{l}\text { Start of live } \\
\text { (face) enrollment }\end{array}$ & $\begin{array}{l}\text { October 2005. A } \\
\text { new passport } \\
\text { system with live } \\
\text { enrollment im- } \\
\text { plemented since } \\
\text { 2005. Photos are } \\
\text { stored on the } \\
\text { chip. Since } 2009 \\
\text { also fingerprints. }\end{array}$ & $\begin{array}{l}\text { 2005. Fingerprints } \\
\text { were added in } \\
2010 \text {. Iris biomet- } \\
\text { rics is not used, } \\
\text { but the system is } \\
\text { being prepared for } \\
\text { that option. }\end{array}$ & 2008. & $\begin{array}{l}\text { May 2007. Man- } \\
\text { datory live fin- } \\
\text { gerprint enroll- } \\
\text { ment since June } \\
2009 \text {. }\end{array}$ \\
\hline $\begin{array}{l}\text { Mandatory live } \\
\text { enrollment ex- } \\
\text { ceptions and } \\
\text { problems (age, } \\
\text { disabilities, etc) }\end{array}$ & $\begin{array}{l}\text { The in-person } \\
\text { meeting is more } \\
\text { important for the } \\
\text { elderly. People } \\
\text { with disabilities } \\
\text { may have prob- } \\
\text { lems applying } \\
\text { and there is con- } \\
\text { tinuous work to } \\
\text { alleviate this. } \\
\text { The use of mo- } \\
\text { bile application } \\
\text { equipment is } \\
\text { being investigat- } \\
\text { ed. }\end{array}$ & $\begin{array}{l}\text { A future method } \\
\text { for improving } \\
\text { convenience is } \\
\text { using mobile ap- } \\
\text { plication kiosks. } \\
\text { This way the el- } \\
\text { derly do not have } \\
\text { to travel to the } \\
\text { police but the } \\
\text { police can go to } \\
\text { retirement homes, } \\
\text { hospitals, etc. } \\
\text { Police can also } \\
\text { visit schools. } \\
\text { These mobile } \\
\text { kiosks may be } \\
\text { used for both } \\
\text { passports and } \\
\text { national ID-cards. }\end{array}$ & $\begin{array}{l}\text { There have been } \\
\text { no major usage } \\
\text { problems. }\end{array}$ & $\begin{array}{l}\text { There are vari- } \\
\text { ous options } \\
\text { available to in- } \\
\text { crease usage } \\
\text { convenience. }\end{array}$ \\
\hline
\end{tabular}

Source: Authors.

\section{Literature Review}

Studies on ICT-driven innovation in the public sector frequently emphasize the organizational, administrative, and political context as a source of innovation drivers and barriers. Since the application of the live enrollment requires changes in organizational workflows and coordination between different organizations, it faces a number of organizational barriers. Such barriers involve, for example, existing governmental silos and lack of communication, the complexity of organizational change, and concerns about high implementation costs.

Studies have found that the innovation capacity of public sector organizations depends on a number of organizational factors, such as organizational structures, intra- and inter-organizational collaboration and coordination, organizational culture, leadership styles (De Vries et al., 2016; European Commission, 2013), resources (Bekkers et al., 2013), qualified personnel (Alshehri and 
Drew, 2011), etc. Public sector organizations are also strongly affected by the legal culture and administrative traditions of the state (Bekkers et al., 2013). Moreover, the inherent complexity of public sector organizations and their accountability to a multitude of stakeholders make the implementation of organizational changes much more difficult in the public sector than it is in the private sector (Rashman et al., 2009).

Although the public sector context generates more barriers than drivers to innovation, some drivers still exist. Firstly, drivers may be generated by external triggers, such as competitive pressure by other organizations, countries or international bodies (Bekkers et al., 2013), legal obligation, political priority, and public demand (De Vries et al., 2016). At the organizational level, innovation can be driven by participation in cross-organizational and cross-border knowledge transfer networks (Albury, 2005), and strong leadership by administrative and political managers (Bekkers et al., 2013).

The regulatory and legal context is perceived to be important in several respects. On the one hand, existing regulations often stifle innovation; on the other, regulations can also promote innovation, for example by imposing a legal obligation to implement certain solutions (De Vries et al., 2016).

Another potentially important factor is that demand by citizens and businesses can act as an influential factor for live enrollment. In order to understand what factors affect the demand and acceptance of live enrollment, research on the acceptance and use of technology can provide valuable insights. The general point of departure of such literature is the understanding that there are a number of factors that influence the user as to whether or not to adopt a novel technology. One popular approach for mapping those factors is the technology acceptance model (TAM), which argues that acceptance is determined by the perceived usefulness and ease of use of a technology (Davis, 1989). TAM's derivative-the Unified Theory of Acceptance and Use of Technology (UTAUT) is more elaborate and incorporates additional factors, explaining how a decision is formed about the use of an information system. The theory builds on four key constructs: 1) performance expectancy, 2) effort expectancy, 3) social influence, and 4) facilitating conditions (Venkatesh, 2000; Venkatesh et al., 2012).

\section{Hypotheses}

On the basis of the conducted theoretical research and previous empirical work, we have formulated several specific hypotheses about barriers and drivers of full live enrollment. This includes aspects pertaining to both the users-individuals expected to use the live enrollment service-as well as the suppliers of said public service. The hypotheses are summarized as follows:

1. Increasing security in the identification of persons is the primary motivation for the introduction of live enrollment;

2. Continuous political support from stakeholders (both internal and external) is a driver for implementing live enrollment; 
3. Adequate financial resources (e.g., cost-efficiency) and technology are drivers for implementing live enrollment;

4. Commitment and leadership (e.g., agencies being ready to take on additional tasks) is a driver for implementing live enrollment;

5. ICT awareness and capabilities (e.g., technology familiarity and user-friendliness) are drivers for implementing live enrollment.

Our key hypotheses are related to the expectations of the government when introducing live enrollment. We expect security related benefits, such as making sure the photo comes from the person who is applying for a passport and is not altered in any way-as well as other kinds of protection from document forgery. In addition, central arguments around introducing live enrollment relate to the accuracy and reliability of the identification of persons and protection from identity theft. We also expect to see more general public security policy objectives, such as the fight against illegal immigration and human trafficking, as well as the fight against terrorism and serious crime. (Hoepman et al. 2006; Tiits et al., 2014)

Even when live enrollment is used, there remain potential weaknesses in the system. For instance, checks for duplicates in passport registries are still usually limited to manual searches or identification (rather than verification) algorithms due to the inherent complexity. Also, the distribution of a manufactured passport is not necessarily done with the applicant picking it up in person. Furthermore, live facial capture can be thwarted if the clerk does not pay enough attention, therefore, letting the applicant bypass the system by e.g. holding a photo in front of the face or by using make-up and masks. The original basis of identification also remains a vulnerable point. Indeed, breeder documents issued at birth, improved recognition, and mimicking technology may give rise to questions regarding the very nature of identity.

All weak links limit the security benefits of live enrollment. For instance, the possible advantages of live enrollment would likely be greater for those who have implemented automatic border gates that can make better use of the captured biometrics. The same applies to the prevalence of passport (identification) checks-e.g. anywhere on the territory rather than very sparsely.

We expect the general key barriers and drivers of public sector innovation to be the same for the specific case of live enrollment, with the importance of continuous political support to the process, financial resources, the commitment and leadership of administrative and technical managers ("championing of the project"), ICT awareness, and capabilities of the stakeholders (systems, skills, tools and methods) (De Vries et al., 2016; European Commission, 2013; Kalvet, 2012).

Existence of a suitable live enrollment technology on the local market, or suppliers who can provide it, might also be important as well as related business models. The cost of implementing live enrollment may also be mitigated by similar existing systems and solutions. If live enrollment for ID cards is already in place, the step towards live enrollment for passports should be considerably easier. Extensive population censuses (registries) can further help, as there will be more information in the system already. Conversely, going for live enrollment could also be made easier if other changes were already needed for the passport application process, such as introducing fingerprint scanners. 
Any security measure must be cost-efficient and in some cases it may be that population density (e.g. in relation to the number of application offices) is too low to offset the cost of live enrollment. On the other hand, live enrollment could be a more cost-effective security measure than e.g. ones based on complex certificate distribution, or instead less cost-effective than putting a limit to the amount of new passports a citizen is allowed in a set period of time.

As public sector innovation is risky, we expect to see evidence of resistance from some stakeholders (e.g., agencies reluctant to take on additional tasks). This may be particularly likely in the case of procedures that were recently changed. Related to this is the use of formalized methodological approaches to implementing the change (a clear definition of work rules and methods, training, etc.) in order to mitigate the risks. Since the general experience in public sector innovations is one of limited attention being paid to precise systematic gathering and use of measurement and data, we do not expect to see very clear measurable target indicators set in relation to live enrollment.

There are also certain probable expectations from the public that can influence live enrollment uptake (Kalvet et al., 2018b). Convenience of the collection of photos (e.g. easier to use photo booth rather than making the extra effort to visit a professional photographer) and image satisfaction are likely important factors. Furthermore, the spread of digital cameras could have a two-sided effect: on the one hand, it might encourage uptake of related technologies such as live enrollment, while on the other hand, resistance from professional photographers due to an increasingly smaller market may appear. We also expect to see some problems due to the innovative nature of technology. Societal groups such as those less familiar with technology and digital photography may be more risk-averse and resistant to live enrollment, preferring the traditional method; age and profession distribution of a region or country may be underlying factors here. Pre-existing widespread use of privacy-sensitive technology, like biometrics and databases, may make live enrollment easier to accept. For instance, fingerprint usage has previously had bad connotations due to the connection with criminal records, but this has been alleviated by the rising use of fingerprint logins on smartphones.

Finally, since the main purpose of passports is to travel to other jurisdictions, a country must consider not only its own perceptions but also external pressure. For instance, countries must take into account demands from the EU and International Civil Aviation Organization (ICAO) in addition to particular countries like the US requiring certain procedures to ensure visa-free entry.

These specific hypotheses were the main topics focused on in the interviews and other data collection methods, and in the following section key findings are discussed.

\section{Discussion}

If current facial recognition algorithms are unable to fully deal with digital image alterations, and live enrollment (where photos are taken in a controlled environment in the application office) provides a way of alleviating this risk; then, the question becomes why are all countries not already using it. Our research shows that some countries have switched to live enrollment 
successfully, while many still use the traditional method of having citizens bring photos when applying for a passport. Also, many countries allow both methods.

Building on the theories of public sector innovation, acceptance, and use of technology, the authors have identified a number of factors influencing live enrollment decisions and implementations. These factors may be split between those behind the decision to switch to live enrollment and the factors impacting the ease of implementation.

\subsection{Making the Decision to Go Live}

A main driver for live enrollment is increased security, which hinders false images in passports. Furthermore, live enrollment is convenient for citizens, as they do not need to first acquire photos before visiting the application office. Also, formatting issues are unlikely to occur if all photos are taken by the same organization. However, all security measures must be weighed against the different associated potential costs. For instance, the passport authority will need to administer photos in a different way, while portrait photographers lose a fairly substantial part of their income. Photos not taken by experienced photographers may also lead to less flattering portraits, which may be associated with a decrease in satisfaction among citizens. Some photographers have indicated that they believe they could provide as secure an image process as the government officials, but this may ultimately be a question of trust.

There may also be old connotations of feeling like a criminal attached to biometrics being captured by the authorities, and care must be taken to give applicants sufficient privacy-especially for those with certain religious beliefs or disabilities. Indeed, the passport authorities in Sweden and Norway are both trying to be service-minded and create good will.

Another factor affecting the decision of switching to live enrollment is the external global pressure from organizations like the EU and ICAO, as well as influential countries like the USA that require certain procedures for visa free entry. In general, however, EU member states seem to be doing very well with passport security in an international context. There may be pressure coming from other countries having implemented live enrollment or incentives coming from other parts of one's own government that use similar technology. On the other hand, traditions may be strong and if a country recently changed its application procedures, it will likely be more reluctant to do so again.

It is also interesting to note that the motivation for going live has been rather different in our case study countries. Estonian prioritized the quality of photos, as the photos were previously not always of sufficient quality, while security considerations, such as avoiding photo morphing were not of concern. Contrastingly, for Kosovo, Sweden, and Norway security considerations were the highest. For Estonia, user convenience has been very important and is behind the decision of keeping alternative application processes open for the citizens.

Another finding is that in the absence of legacy systems (like in Kosovo), more profound decisions are generally reached (and implemented) in an easier fashion. Also, it must be reiterated that decisions are easier to reach if there are other organizations that have introduced live enrollment 
for related services; it is possible to learn from their experience and somehow pressure to innovate is created from the public side if they have positive experiences with live enrollment in other contexts.

In general, still, decisions to employ live enrollment seem to be influenced equally by both the contexts in relation to external from public sector organizations, as well as by organizational level factors. External pressures alone (such as security related considerations by politicians) cannot explain the decisions to switch, as more countries would have switched to live enrollment by now. Suitable organizational level context (including supportive organizational culture and allocation of resources), coupled with individual level drivers of key persons (such as job-related knowledge/skills and willingness to exploit risky avenues) behind the live enrollment introduction, were also needed.

Table 2: Motivational factors in Sweden, Norway, Kosov,o and Estonia

\begin{tabular}{|l|l|l|l|l|}
\hline & Sweden & Norway & Kosovo & Estonia \\
\hline $\begin{array}{l}\text { Security as mo- } \\
\text { tivation for the } \\
\text { introduction of } \\
\text { live enrollment }\end{array}$ & $\begin{array}{l}\text { Secure documents } \\
\text { and a simplified } \\
\text { process as im- } \\
\text { portant drivers. }\end{array}$ & $\begin{array}{l}\text { Secure identifica- } \\
\text { tion and address- } \\
\text { ing the look-a-like } \\
\text { problems im- } \\
\text { portant. Further, } \\
\text { immigration is- } \\
\text { sues and fight } \\
\text { against crime im- } \\
\text { portant. }\end{array}$ & $\begin{array}{l}\text { Higher document } \\
\text { security as im- } \\
\text { portant driver. }\end{array}$ & $\begin{array}{l}\text { Security was not } \\
\text { a key driver as } \\
\text { applicants' pho- } \\
\text { tos were com- } \\
\text { pared to those } \\
\text { already in the } \\
\text { registry in order } \\
\text { to secure the } \\
\text { chain of identi- } \\
\text { ty. }\end{array}$ \\
\hline $\begin{array}{l}\text { Cost-efficiency } \\
\text { and quality as } \\
\text { motivation for } \\
\text { the introduction } \\
\text { of live enroll- } \\
\text { ment }\end{array}$ & $\begin{array}{l}\text { Not an important } \\
\text { factor. }\end{array}$ & $\begin{array}{l}\text { Improving con- } \\
\text { sistency/ease of } \\
\text { making sure a } \\
\text { photograph was } \\
\text { correctly format- } \\
\text { ted. It used to take } \\
\text { time for the police } \\
\text { to scan photos, } \\
\text { check quality, etc } \\
\text { and quality was } \\
\text { overall worse. } \\
\text { Cost-efficiency } \\
\text { especially im- } \\
\text { portant to police. }\end{array}$ & $\begin{array}{l}\text { Increase efficiency } \\
\text { as an important } \\
\text { driver. }\end{array}$ & $\begin{array}{l}\text { Expectation for } \\
\text { better quality } \\
\text { photos was key } \\
\text { driver. }\end{array}$ \\
\hline $\begin{array}{l}\text { User- } \\
\text { friendliness as } \\
\text { motivation for } \\
\text { the introduction } \\
\text { of live enroll- } \\
\text { ment }\end{array}$ & $\begin{array}{l}\text { Not an important } \\
\text { factor. }\end{array}$ & $\begin{array}{l}\text { Increased usabil- } \\
\text { ity and customer } \\
\text { (citizen) satisfac- } \\
\text { tion no the key } \\
\text { driver. }\end{array}$ & $\begin{array}{l}\text { Not an important } \\
\text { factor. }\end{array}$ & $\begin{array}{l}\text { Convenience } \\
\text { and user- } \\
\text { friendliness } \\
\text { very important. } \\
\text { Hence, also the } \\
\text { decision not to }\end{array}$ \\
\hline
\end{tabular}




\begin{tabular}{|c|c|c|c|c|}
\hline & Sweden & Norway & Kosovo & Estonia \\
\hline & & & & $\begin{array}{l}\text { make it manda- } \\
\text { tory. Organiza- } \\
\text { tion in charge of } \\
\text { issuing driver's } \\
\text { licenses had } \\
\text { introduced live } \\
\text { enrollment al- } \\
\text { ready giving } \\
\text { rise to expecta- } \\
\text { tions for similar } \\
\text { services else- } \\
\text { where. }\end{array}$ \\
\hline $\begin{array}{l}\text { External factors } \\
\text { as motivation } \\
\text { for the intro- } \\
\text { duction of live } \\
\text { enrollment }\end{array}$ & $\begin{array}{l}\text { ICAO's recom- } \\
\text { mendations, alt- } \\
\text { hough not manda- } \\
\text { tory, important. In } \\
\text { contrast, the US } \\
\text { often successfully } \\
\text { exerts pressure, } \\
\text { even though they } \\
\text { lack good quality } \\
\text { themselves. }\end{array}$ & $\begin{array}{l}\text { External pressure } \\
\text { from, e.g. the US, } \\
\text { was not a driver. } \\
\text { However, EU has } \\
\text { been driving the } \\
\text { development } \\
\text { even though } \\
\text { Norway is not a } \\
\text { member state. } \\
\text { There may also } \\
\text { be some prestige } \\
\text { involved in being } \\
\text { the first to im- } \\
\text { plement live. }\end{array}$ & $\begin{array}{l}\text { Compliance with } \\
\text { ICAO recommen- } \\
\text { dations/ standards } \\
\text { for passports and } \\
\text { EU security fea- } \\
\text { tures recommen- } \\
\text { dations. }\end{array}$ & $\begin{array}{l}\text { Extensive ex- } \\
\text { ternal funding } \\
\text { was available } \\
\text { from Schengen } \\
\text { Facility. Oth- } \\
\text { erwise live en- } \\
\text { rollment would } \\
\text { probably have } \\
\text { been delayed or } \\
\text { not introduced } \\
\text { at all. }\end{array}$ \\
\hline
\end{tabular}

Source: Authors.

\subsection{Implementing Live Enrollment}

Even if the decision is made to introduce live enrollment, proper risk management is needed to account for any and all setbacks encountered during implementation. One possible risk is that appropriate technology is missing or that vendors do not have suitable offerings. There are not many vendors available and, as such, there is low competition that may have led to higher prices and questionable quality. There are ideas of certifying vendors to address this. One of the typical problems related to public sector innovation is related to the lack of suitable technology in the market. Thus, there is need to continue development of related technologies until they can be applied. This also calls for the implementation of rather unpopular public procurement mechanism, so-called public procurement of innovation. In the case of live enrollment, suitable solutions did exist in the global market. However, it should be noted that any vendor winning a particular procurement process would effectively have a monopoly for live enrollment in the applicable region and at the time of that procurement. As such, there is considerably more at stake than in the case of non-live enrollment, where there can be many simultaneous vendors sharing the market. Thus, care must be taken in order not to let corruption distort the procurement process. 
Furthermore, staff must be trained. In an unstable political situation, a decision may soon be reversed, and idea championing and motivation could become limited. Overall, a culture rife with innovation will be more accustomed to and prepared for changes and, therefore, more likely to succeed with a change in enrollment processes. Of special concern is when passport applications are done for extraordinary circumstances, such as when conducted outside of one's country, when applying for temporary/emergency passports, or when applying for visas. Indeed, citizens seem to highly value the speed of the application process, with examples of citizens making sure they get passports with the old ten-year validity before a switch to a mere five-year validity. In general, citizens seem more concerned about the use of fingerprints and biometric data in databases than about live enrollment. Passport officials have suggested changing the discourse and instead focusing on the improved security measures to stop identity theft.

Our research confirms that one of the typical weaknesses associated with insufficient attention to the use of impact assessments and evaluations is also true regarding live enrollment. None of the countries set target indicators nor was their achievement monitored. Neither have we encountered (public) impact assessments of the benefits of live enrollment (that in turn might slow down other countries to switch as the benefits are debatable).

Our research of technology acceptance aspects did not reveal problems. The overall societal context was supportive, as people already had experiences with digital photography and automated service machines, generally.

Table 3: Implementation of live enrollment in Sweden, Norway, Kosovo, and Estonia

\begin{tabular}{|c|c|c|c|c|}
\hline & Sweden & Norway & Kosovo & Estonia \\
\hline $\begin{array}{l}\text { Difficulties } \\
\text { and obstacles } \\
\text { when imple- } \\
\text { menting live } \\
\text { enrollment }\end{array}$ & $\begin{array}{l}\text { A lot of organiza- } \\
\text { tional inertia. } \\
\text { Obtaining of } \\
\text { funding took } \\
\text { some effort. Effort } \\
\text { by the police to } \\
\text { convince people } \\
\text { biometrics and } \\
\text { security is for the } \\
\text { citizens' sake, } \\
\text { stopping identity } \\
\text { theft. Some tech- } \\
\text { nical issues re- } \\
\text { main - photos are } \\
\text { now taken with } \\
\text { wide angles that } \\
\text { can give wrong } \\
\text { perspectives, to } \\
\text { be fixed with im- } \\
\text { provement of } \\
\text { technology. }\end{array}$ & $\begin{array}{l}\text { Political support } \\
\text { was considered } \\
\text { important and took } \\
\text { some effort. Sup- } \\
\text { port has increased } \\
\text { in time, possibly } \\
\text { because of immi- } \\
\text { gration putting } \\
\text { focus on the issue. } \\
\text { The initial cost } \\
\text { may stop other } \\
\text { countries from } \\
\text { following suit. De- } \\
\text { preciation of the } \\
\text { technology used } \\
\text { and demand for } \\
\text { higher quality pho- } \\
\text { tos currently on } \\
\text { agenda. }\end{array}$ & $\begin{array}{l}\text { No major imple- } \\
\text { mentation issues. } \\
\text { Perceived in- } \\
\text { crease in efficien- } \\
\text { cy helped the } \\
\text { implementation } \\
\text { process. Small } \\
\text { country so easier } \\
\text { to make decisions } \\
\text { and implement. } \\
\text { Some legislative } \\
\text { changes were } \\
\text { needed. Cooper- } \\
\text { ation with tech- } \\
\text { nology vendors } \\
\text { as well as with } \\
\text { and between min- } \\
\text { istries. Availabil- } \\
\text { ity of experienced } \\
\text { staff helpful for } \\
\text { transition. }\end{array}$ & $\begin{array}{l}\text { No difficulties } \\
\text { observed. Overall } \\
\text { innovation- } \\
\text { friendliness in } \\
\text { society supported } \\
\text { such develop- } \\
\text { ments. Thorough } \\
\text { mapping of avail- } \\
\text { able technologies } \\
\text { and on suitability } \\
\text { in preparatory } \\
\text { stage helped. A } \\
\text { pilot was first im- } \\
\text { plemented in one } \\
\text { of the stations. } \\
\text { Thorough sup- } \\
\text { porting instruction } \\
\text { manuals were de- } \\
\text { veloped to guide } \\
\text { staff. Special civil } \\
\text { servant was intro- }\end{array}$ \\
\hline
\end{tabular}




\begin{tabular}{|c|c|c|c|c|}
\hline & Sweden & Norway & Kosovo & Estonia \\
\hline & & & & $\begin{array}{l}\text { duced to assist } \\
\text { users (still com- } \\
\text { mon practice to- } \\
\text { day). }\end{array}$ \\
\hline $\begin{array}{l}\text { Reaction to } \\
\text { live enroll- } \\
\text { ment by the } \\
\text { general public }\end{array}$ & $\begin{array}{l}\text { Some applicants } \\
\text { worry the pic- } \\
\text { tures do not real- } \\
\text { ly look like them } \\
\text { and clerks may } \\
\text { allow retaking of } \\
\text { photos several } \\
\text { times. It's a good- } \\
\text { will issue. } \\
\text { Privacy not a ma- } \\
\text { jor concern, and } \\
\text { religious reasons } \\
\text { prohibiting public } \\
\text { exposure of the } \\
\text { face are solved by } \\
\text { using curtains. }\end{array}$ & $\begin{array}{l}\text { The applicant may } \\
\text { retake the photo } \\
\text { "until happy". } \\
\text { Applicant not get- } \\
\text { ting separate copy } \\
\text { of photo not an } \\
\text { issue. Privacy and } \\
\text { religious beliefs } \\
\text { addressed at point } \\
\text { of enrollment by } \\
\text { using a curtain } \\
\text { around photo } \\
\text { booth. }\end{array}$ & $\begin{array}{l}\text { Applicants are } \\
\text { given } 2 \text { or } 3 \text { pos- } \\
\text { sibilities to retake } \\
\text { photo. Citizens } \\
\text { do not have suffi- } \\
\text { cient awareness } \\
\text { in order to think } \\
\text { to make com- } \\
\text { plaints regarding } \\
\text { privacy and bio- } \\
\text { metrics. }\end{array}$ & $\begin{array}{l}\text { Positively received } \\
\text { by all stakehold- } \\
\text { ers. Photo quality } \\
\text { has become better; } \\
\text { even if a person } \\
\text { shows up with a } \\
\text { non-eligible photo, } \\
\text { it is possible to } \\
\text { retake the photo } \\
\text { in-house. }\end{array}$ \\
\hline $\begin{array}{l}\text { Reaction to } \\
\text { live enroll- } \\
\text { ment by pho- } \\
\text { tographers }\end{array}$ & $\begin{array}{l}\text { Concerns of live- } \\
\text { lihood threat- } \\
\text { ened, especially } \\
\text { since advent of } \\
\text { personal digital } \\
\text { cameras, which } \\
\text { were misjudged } \\
\text { by photogra- } \\
\text { phers. Probably } \\
\text { due to lacking } \\
\text { communication } \\
\text { between gov- } \\
\text { ernment and the } \\
\text { photographers } \\
\text { with the news } \\
\text { breaking rather } \\
\text { late and causing } \\
\text { a shock. } \\
\text { A photographers' } \\
\text { association as- } \\
\text { serted that live } \\
\text { enrollment dis- } \\
\text { regarded portrait } \\
\text { artistry, tradition, } \\
\text { and the appli- } \\
\text { cant's comfort } \\
\text { and image ap- }\end{array}$ & A non-issue. & $\begin{array}{l}2008 \text { was when } \\
\text { the Kosovo pass- } \\
\text { port was intro- } \\
\text { duced. The pho- } \\
\text { tographers' asso- } \\
\text { ciation sent a } \\
\text { letter to the Min- } \\
\text { istry asking to be } \\
\text { allowed to take } \\
\text { photos rather } \\
\text { than with live } \\
\text { enrollment. But } \\
\text { the association } \\
\text { was not strong } \\
\text { enough to suc- } \\
\text { ceed. The state } \\
\text { was anyway con- } \\
\text { vinced live en- } \\
\text { rollment was the } \\
\text { best way. } \\
\text { Live enrollment } \\
\text { (for IDs) started } \\
\text { in } 2000 \text { and back } \\
\text { then there was } \\
\text { no issue with the } \\
\text { advent of digital } \\
\text { cameras. }\end{array}$ & $\begin{array}{l}\text { Photographers (as } \\
\text { a stakeholder } \\
\text { group) were con- } \\
\text { sulted in the pro- } \\
\text { cess. Although } \\
\text { they did see their } \\
\text { market shares } \\
\text { decreasing as a } \\
\text { result, their posi- } \\
\text { tion was that for } \\
\text { "beautiful pass- } \\
\text { port photos" one } \\
\text { should still use } \\
\text { their services. }\end{array}$ \\
\hline
\end{tabular}




\begin{tabular}{|l|l|l|l|l|}
\hline & Sweden & Norway & Kosovo & Estonia \\
\hline & $\begin{array}{l}\text { pearance satisfac- } \\
\text { tion (Hyltner, } \\
\text { 2005). They also } \\
\text { stressed that cor- } \\
\text { porations are } \\
\text { allowed other } \\
\text { sensitive official } \\
\text { tasks (Hyltner, } \\
\text { 2005). }\end{array}$ & & & \\
\hline
\end{tabular}

Source: Authors.

\subsection{A Multi-faceted Situation}

The interviews revealed varying experiences, obstacles, cultural differences, and trade-offs. Only in Sweden was the voice of the photographers an issue. Indeed, Estonia may have found a move towards live enrollment easy, since they also kept the traditional application method. However, Norway also went full live and, in fact, had a lot of political support and funding; although, the support and funding varied over time. Kosovo, being a rather young country, seems to have succeeded with implementing live enrollment thanks to no pre-existing alternatives. While there were some discussions among photographers, their voices were not very strong. Furthermore, the issue was not particularly political, in part thanks to a small government. Also, since Kosovo's efforts started as early as 2000, there was no issue with the advent of digital cameras further affecting photographers.

The other parts of the identification chain were also important influencers. The existence and levels of birth registries vary widely in the EU, as do the use of automatic border gates, mobile application kiosks, and restrictions on citizens' rights to a passport. The use and sophistication of other forms of ID may also play a role. For instance, the Swedish transport authority previously tried but failed to implement live enrollment for driver's licenses. Now, they plan to revisit this with the learned experiences of the passport authority.

\section{Conclusions}

Using live enrollment for passports (where photos are taken in the application office, is a topical issue) (Behrensen et al., 2016), since it can limit the possibility of malicious digital image alterations. However, live enrollment has both its advantages and disadvantages, and a trade-off is expected. Live enrollment may make passport applications a one-stop process, ensure consistent formatting, and increase security. There may also be spill-over effects. For example, Estonia first introduced live enrollment for driver's licenses, and this experience simplified introduction of the live enrollment for passports. Sweden is following a reversed path from live passport enrollment, thus, making the similar move for licenses simpler. External pressure can also be international e.g. from the ICAO or EU. 
However, live enrollment is a break with tradition, and depends on overhauls in the public sector where measurable targets and risk management is typically wanting. In addition, the passport authority may be reluctant to take on new tasks. The public may hesitate to trust the government further with their private data and find that their portraits are now less flattering. Furthermore, live enrollment can make it more difficult for expats, who need to apply for a passport from abroad. Moreover, a lack of competition among live enrollment equipment vendors may lead to high prices for low-quality, which both Sweden and Norway have found. Portrait photographers meanwhile suffer loss of income.

To minimize the trade-off, authorities have tried becoming more service-minded by creating good will, and not just in relation to the speed of the application process (though it is highly important to applicants). Portrait photographers, on the other hand, have suggested that they be certified, in a similar vein to what is done in other areas where the private sector provide a service for the public good, thereby ensuring adequate levels of security. However, at least so far their suggestions have not become a reality. In the case study of four countries, only in Sweden was the voice of the photographers at all an issue, and even there the authorities chose to prioritize security and live enrollment.

The decision to introduce live enrollment and the state of live enrollment in Europe are both multi-faceted. Experiences, drivers, and obstacles vary between countries and sometimes there are even more regional structures where one part of a country differs from another. Furthermore, it is not a binary decision: there are different versions of live enrollment implementations and also mix enrollment where live enrollment is offered but not mandatory, such as in Estonia. What is more, when planning the introduction of live enrollment, Estonia prioritized quality of photos and userfriendliness, whereas Sweden focused on security. Implementation wise, Kosovo benefitted from a small government and no pre-existing alternatives, while also pre-empting the digital camera era that later put more pressure on photographers. Norway had substantial political support and funding, although the backing varied over time, while Estonia utilized Schengen funds.

As such, the decision to introduce live enrollment and successful implementation, is dependent on a vast number of cultural and political factors. Straightforward sociocultural models are unable to fully explain the current situation and other factors must be considered like the overall state of a country's passport maturity with its automatic border gates, mobile application kiosks, restrictions on passport renewals, as well as the proliferation of birth registries and the security of breeder documents.

Several limitations remain, however. First, the attitudes of photographers (as an important stakeholder group) could be studied further. They might be hard to reach, though, as those who suffered economically due to live enrollment could no longer be in business. Also, empirical data could be collected from the countries that do not practice live enrollment now to deepen current results, especially in understanding the reasons they have not gone live and on understanding the commonalities of the non-live countries, such as large( $\mathrm{r}$ ) population size or weakness of social norms. Also, it would be interesting to study the live enrollment outside of the EU to get more generalizable results. Finally, as indicated by the interviewees, proper impact assessment studies 
would be relevant to understand if goals of the live enrollment have actually be reached, such as the increasing of security.

\section{References}

Albury, D. (2005). Fostering Innovation in Public Services. Public Money \& Management, 25, 51-56.

Alshehri, M., \& Drew, S.J. (2011). E-government principles: implementation, advantages and challenges. International Journal of Electronic Business, 9, 255-270.

Behrensen, M., Kalvet, T., Kindt, E., Tiits, M., \& Palm, E. (2016). Harmonization of ePassport and Border Checks in the European Union: Ethical, Social, and Legal Aspects. A summary of the practical implications of the legal, ethical, and social analysis of the FIDELITY project.

Bekkers, V., Tummers, L., \& Voorberg, W. (2013). From public innovation to social innovation in the public sector: A literature review of relevant drivers and barriers. Rotterdam: Erasmus University Rotterdam.

Davis, F.D. (1989). Perceived usefulness, perceived ease of use, and user acceptance of information technology. MIS Quarterly, 13(3), 319-340.

De Vries, H., Bekkers, V., \& Tummers, L. (2016). Innovation in the Public Sector: A Systematic Review and Future Research Agenda. Public Administration, 94(1), 146-166.

European Commission. (2013). Powering European Public Sector Innovation: Towards A New Architecture. Report of the Expert Group on Public Sector Innovation.

Ferrara, M., Franco, A., \& Maltoni, D. (2014). The Magic Passport. IEEE International Joint Conference on Biometrics (IJCB), 1-7.

Hoepman, J.-H., Hubbers, E., Jacobs, B., Oostdijk, M., \& Schreur, R.W. (2006). Crossing Borders: Security and Privacy Issues of the European e-Passport. 1st Int. Workshop on Security, Kyoto, Japan, October 2324. http://arxiv.org/abs/0801.3930.

Hyltner, 2005. Utredning avseende proposition 2004/05:119, Ökad säkerhet i pass m.m., Stiftelsen Den Nya Välfärden.

Kalvet, T. (2012). Innovation: a factor explaining e-government success in Estonia. Electronic Government, an International Journal, 9, 142-157.

Kalvet, T., Tiits, M., Ubakivi-Hadachi, P. (2018a). Risks and Societal Implications of Identity Theft. In: Proceedings of the Internationsl Conference on Electronic Governance and Open Society: Challenges in Eurasia (EGOSE 2018). Springer: Lecture Notes in Computer Science.

Kalvet, T., Tiits, M., \& Laas-Mikko, K. (2018b). Public Acceptance of Advanced Identity Documents. In Proceedings of the 11th International Conference on Theory and Practice of Electronic Governance (ICEGOV'18), Galway, Ireland, April 2018.

Rashman, L., Withers, E., \& Rashman, J.H. (2009). Organizational learning and knowledge in public service organizations: A systematic review of the literature. International Journal of Management Reviews, 11(4), 463-494. 
Tiits, M., Kalvet, T., \& Laas-Mikko, K. (2014). Social Acceptance of ePassports. Lecture Notes in Informatics P$230,15-26$.

Venkatesh, V. (2000). Determinants of Perceived Ease of Use: Integrating Control, Intrinsic Motivation, and Emotion into the Technology Acceptance Model. Information Systems Research, 11(4), 342-365.

Venkatesh, V., Thong, J.Y.L., \& Xu, X. Consumer acceptance and use of information technology: extending the unified theory of acceptance and use of technology. MIS Quarterly 36(1) 157-178 (2012).

\section{About the Authors}

Tarmo Kalvet

Tarmo Kalvet, PhD, is senior research fellow in the field of technology governance at the Ragnar Nurkse Department of Innovation and Governance, Tallinn University of Technology, Estonia, and Director of Research at the Institute of Baltic Studies. He was for many years the founding head of the Innovation Policy Research Program at the Praxis Centre for Policy Studies, Estonia's leading policy think tank, as well as one of its board members. Previously, he has also worked for Archimedes Foundation as an analyst (19992001) and for the "Phare Public Development Program in Estonia" (1997 - 1998). He is currently coordinating a research project "Public sector innovation: The case of modern identity management technologies" (PUT773) from the Estonian Science Foundation.

Henrik Karlzén

Henrik Karlzén is a researcher at the Swedish Defense Research Agency. His research concerns cybersecurity with special focus on risk analysis and policy, employee behavior, future security solutions, cyber operations, and high-security systems in the defense sector. He has previously been involved in a national consortium on information security culture and climate, as well as in work on next generation ePassports (FIDELITY, FP7) aimed at improving the usability, security, efficiency, and reliability of electronic travel documents in the EU.

\section{Amund Hunstad}

Amund Hunstad, received a M. Sc-degree in Computer Science and Engineering from University of Linköping, Sweden. Since 2001, he has been a research staff member at Swedish Defense Research Agency (FOI) in Linköping. His current research interests include IT security, security architectures, biometrics, crisis management, and command and control systems. He has been involved in the EU/FP7-projects FIDELITY and COURAGE.

\section{Marek Tiits}

Dr Marek Tiits, PhD, is chairman of the board of the Institute of Baltic Studies. His particular fields of expertise are technology governance and development economics. He is currently doing research on privacy and ethics aspects of novel critical infrastructure protection systems (ATENA, funded by H2020, project ID 700581). He was previously involved in various identity management projects aimed at studying increasing passport breeder document security, on the identity theft phenomenon in Europe, uncovering the flaws in traditional "paper-based" procedures as well as in the existing electronic identities (ORIGINS, FP7, 607663; EKSISTENZ, FP7, 607049), and fast and trustworthy identity delivery and check with ePassports leveraging traveler privacy (FIDELITY, FP7, 284862). 


\section{Annex 1 - Live enrollment interview guide}

1. Please provide a background and a short description of the current passport enrollment process

a. When were ePassports introduced?

b. Where are the photo booths in the application office?

c. Are automatic border controls in effect?

d. How do applicants identify themselves when applying for, and collecting, passports?

2. What were the expectations of the government, when introducing live enrollment of photos?

a. Security related benefits?

b. Fight against illegal immigration?

c. Fight against human trafficking?

d. Fight against terrorism and serious crime?

e. Did the requirements of visa-free travel of the United States influence the live enrollment of photos?

f. How difficult was it to define measurable targets and measure the progress?

g. How successful have you been in meeting the targets?

3. In relation to live enrollment, how would you describe the:

a. Political support, financial resources, and leadership?

b. Accompanying legislative changes?

c. Existence of suitable live enrollment technology?

i. What is its business model (government owned; leased; pay per application)?

ii. In which similar areas is the private sector relied upon for secure solutions?

d. Stakeholder expectations and societal acceptability:

i. Police reluctance to take on further passport related tasks

ii. Photographers' fear of losing a source of income

iii. The artistic aspect of photography

iv. Safeguarding tradition

v. User-friendliness

vi. Convenience of the collection of photos

vii. Speed and convenience of issuing emergency passports

viii. Privacy aspects

ix. Citizens' irreproachable right to passports

4. Did planning and risk management make the transition easier?

a. Did anything go wrong? How were these difficulties resolved?

5. Was the introduction of the live enrollment of photos different from the live enrollment of fingerprints or ID cards?

a. In terms of the objectives?

b. In terms of the public expectations and societal acceptability?

c. In terms of planning and implementation? 
6. Is there anyone else you would suggest we get in contact with to get further answers to these questions? 